\title{
See It Now or Miss It Forever: Materiality, Visuality, and the Written Word in Janice Kerbel's Recent Artwork
}

\section{Kim Dhillon}

Volume 36, numéro 1, 2011

URI : https://id.erudit.org/iderudit/1066749ar

DOI : https://doi.org/10.7202/1066749ar

Aller au sommaire du numéro

\section{Éditeur(s)}

UAAC-AAUC (University Art Association of Canada | Association d'art des universités du Canada)

\section{ISSN}

0315-9906 (imprimé)

1918-4778 (numérique)

Découvrir la revue

Citer cet article

Dhillon, K. (2011). See It Now or Miss It Forever: Materiality, Visuality, and the Written Word in Janice Kerbel's Recent Artwork. RACAR : Revue d'art canadienne / Canadian Art Review, 36(1), 17-28.

https://doi.org/10.7202/1066749ar

\section{Résumé de l'article}

L'utilisation de l'écriture en tant que médium dans l'art contemporain doit beaucoup aux années 1960 et au mouvement conceptuel ainsi qu'à l'art du début du $\mathrm{XX}^{\mathrm{ème}}$ siècle impliquant le langage écrit dans sa démarche. Néanmoins, les artistes contemporains recourent à ce médium par des voies sophistiquées qui divergent grandement du mouvement conceptuel en associant mots, idées et matériaux d'une manière qui aurait semblé contraire à de nombreux tenants de ce mouvement. Débarrassé de la rhétorique de dématérialisation chère à la critique des années 60 , l'art contemporain s'empare du langage écrit en démontrant non seulement son potentiel à la fois conceptuel, visuel et matériel, mais aussi sa capacité critique autoréflexive. Dans cet essai, nous prenons l'acte de voir/écrire dans l'art conceptuel comme un point de départ pour explorer le travail fondé sur l'enquête et la recherche de l'artiste canadienne Janice Kerbel. Soulignant la façon dont les mots écrits de Kerbel entrent en dialogue avec leur forme visuelle, nous montrons dans le même temps que le contexte dans lequel une oeuvre de ce type est exposée modifie l'interprétation des mots et des codes visuels qu'ils invoquent. L'analyse se concentre plus particulièrement sur Remarkable (2007-10), une série d'affiches typographiques commandées à l'origine par le salon Frieze Art Fair à Londres, puis présentées à l'occasion d'une exposition individuelle de Kerbel à la Tate Britain en 2010.
Tous droits réservés (C) UAAC-AAUC (University Art Association of Canada | Association d'art des universités du Canada), 2011
Ce document est protégé par la loi sur le droit d'auteur. L'utilisation des services d’Érudit (y compris la reproduction) est assujettie à sa politique d'utilisation que vous pouvez consulter en ligne.

https://apropos.erudit.org/fr/usagers/politique-dutilisation/ 


\title{
See It Now or Miss It Forever: Materiality, Visuality, and the Written Word in Janice Kerbel's Recent Artwork
}

\author{
Kim Dhillon, Royal College of Art, London
}

\section{Résumé}

L'utilisation de l'écriture en tant que médium dans l'art contemporain doit beaucoup aux années 1960 et au mouvement conceptuel ainsi qu'à l'art du début du XXème siècle impliquant le langage écrit dans sa démarche. Néanmoins, les artistes contemporains recourent à ce médium par des voies sophistiquées qui divergent grandement du mouvement conceptuel en associant mots, idées et matériaux d'une manière qui aurait semblé contraire à de nombreux tenants de ce mouvement. Débarrassé de la rhétorique de dématérialisation chère à la critique des années 60, l'art contemporain s'empare du langage écrit en démontrant non seulement son potentiel à la fois conceptuel, visuel et matériel, mais aussi sa capacité critique autoréflexive. Dans cet essai, nous prenons l'acte de voir/écrire dans l'art conceptuel comme un point de départ pour explorer le travail fondé sur l'enquête et la recherche de l'artiste canadienne Janice Kerbel. Soulignant la façon dont les mots écrits de Kerbel entrent en dialogue avec leur forme visuelle, nous montrons dans le même temps que le contexte dans lequel une oeuvre de ce type est exposée modifie l'interprétation des mots et des codes visuels qu'ils invoquent. L'analyse se concentre plus particulièrement sur Remarkable (2007-I0), une série d'affiches typographiques commandées à l'origine par le salon Frieze Art Fair à Londres, puis présentées à l'occasion d'une exposition individuelle de Kerbel à la Tate Britain en 2010.

Borderlines: Between Words and Images

B gallery. The five large-format silkscreen posters are initially reserved and unassuming. Despite measuring nearly two metres high, they are somewhat dwarfed by the scale of the wall. A few words stick out. Their much bigger point size captures the eye: "faintgirl," "Iggy Fantuse," and "regurgitating lady." The other words initially recede into bands of black, registering like giant barcodes rather than legible text. The posters are framed, giving them a sense of permanence in this gallery of the Tate Britain. When I stop to read them, the slab-serif typefaces and exclamatory language call at me in the "Roll up! Roll up!" voice of a sideshow hawker announcing his main performers. These posters make up Remarkable (2007-10), a series by Janice Kerbel (b. 1969, Toronto) that employs text without illustration and draws on the tradition of fairground ephemera to conjure up imagined characters (figs. 1-5). The texts announce fairground sideshows that never occur except in the artist's imagination and in the minds of audiences who read the text on the poster. The posters were originally commissioned for the 2007 Frieze Art Fair in London, an art marketplace spectacle. There, they were wallpapered like fly posters throughout the fair, reacting to the carnivalesque mania that surrounded them (fig. 6). Kerbel capitalized on the absurd theatricality of the event, announcing her imaginary sideshow acts with hyperbolic lines like "A great spectral and meteoric wonder \& never before seen." Remarkable brings a new level of visual expression to Kerbel's texts, in which the written word is always in dialogue with its visual form, creating a fiction of illusion, deception, and possibility. Kerbel poses the question: How does visuality of written language interact with the artist's concept, and with the context within which the artwork is shown?

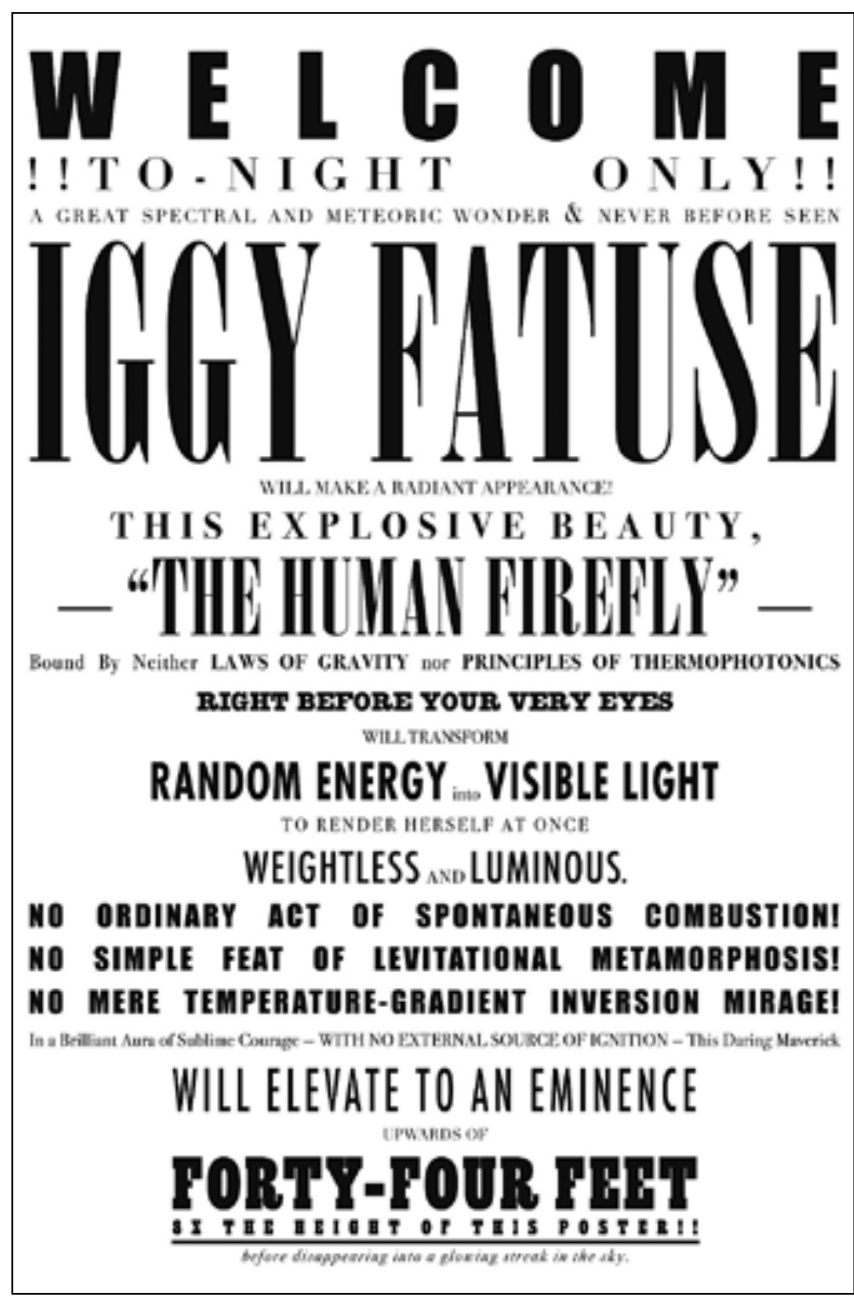

Figure I. Janice Kerbel, Remarkable: Human Firefly, 2007. Silkscreen on campaign poster paper, $165.5 \times 114.5 \mathrm{~cm}$ (Courtesy of greengrassi, London). 
DOUBLE STTRACTION! tDOUELE ATTR ACTION: "DO NOT OVEBLOOK TODAY'S DOEBLE ATTAACTION" GAZE FIXEDLY INTO

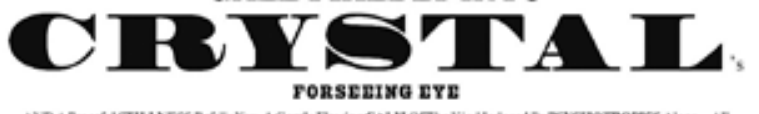

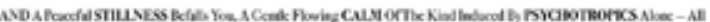

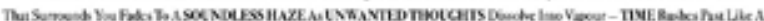

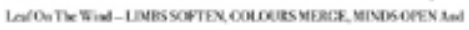

HIIDEN TRUTHS, DISTANT FUTURES COME TO LICHT IN THF

CLOUDY GLOW OF HER MONOCULAR STARE. Look No Further

RICHES! TRAVELS! PASSION! HEALTH! HEARTACHE! DECEPTIOK! BARDSHIP! DESPAIR!

Ia The SINGULAR FOCUS OF HER GUIDING WHITE ORE

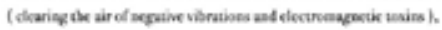

FAR BECOMES NEAR AND THEN BECOMES NOW.

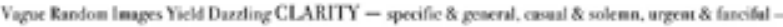
Revealing Your Fine, Secing You Brively On Your Way. - ANTD -

Like A Lizand To A Rock, Like The Sun To The Moon, Like A Fugitive To The Night, BELIEVE WHAT YOU SEE BUT BLTIE AKD YOU'LL MISS

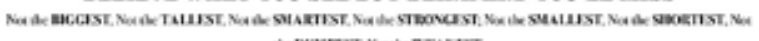

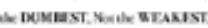

BASHFUL FROM BIRTH

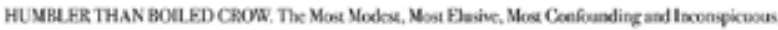
IN THE VERY CORNER OF YOUR EYE

atch efering dieposes

\section{THE SHYEST PERSON ALIVE} mativi,

MASTERFULLY ECLIPSING YOUR GLANCE WITHOUT EVER SHOWING HER FULL CRYPTIC SEUF

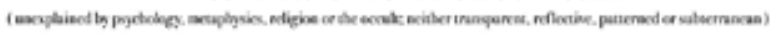

The QUICK SILKY Mones OfThis PERIPHERAL PRESENCE

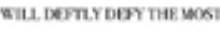

VISUALLV ASTUTE.

Figure 2. Janice Kerbel, Remarkable: Double Attraction-Crystal and Blindspot, 2007. Silkscreen on campaign poster paper, $165.5 \times 114.5 \mathrm{~cm}$ (Courtesy of greengrassi, London).

Janice Kerbel uses the visual quality of written language to create an experiential artwork that is open to the audience's interpretation due to the effable nature of language as a medium. The "writerly"1 experience of Kerbel's art highlights the subjectivity of the work, and in turn, the translation from the artist's intention to the audience's reception. By examining the translations occurring within the artwork, I demonstrate that Kerbel participates in a movement in contemporary practice that traces a trajectory back to Conceptual art, but that engages text in a new and unique way. I attempt to locate in Kerbel's work precisely when the words cease to act as text and begin to operate as image. By discussing the way in which Kerbel uses typography ${ }^{2}$ to give complex text a particular visual, material dimension, I will address the broader contextual implications for modes of production and display of contemporary text-based art. My interest is not in the typographical
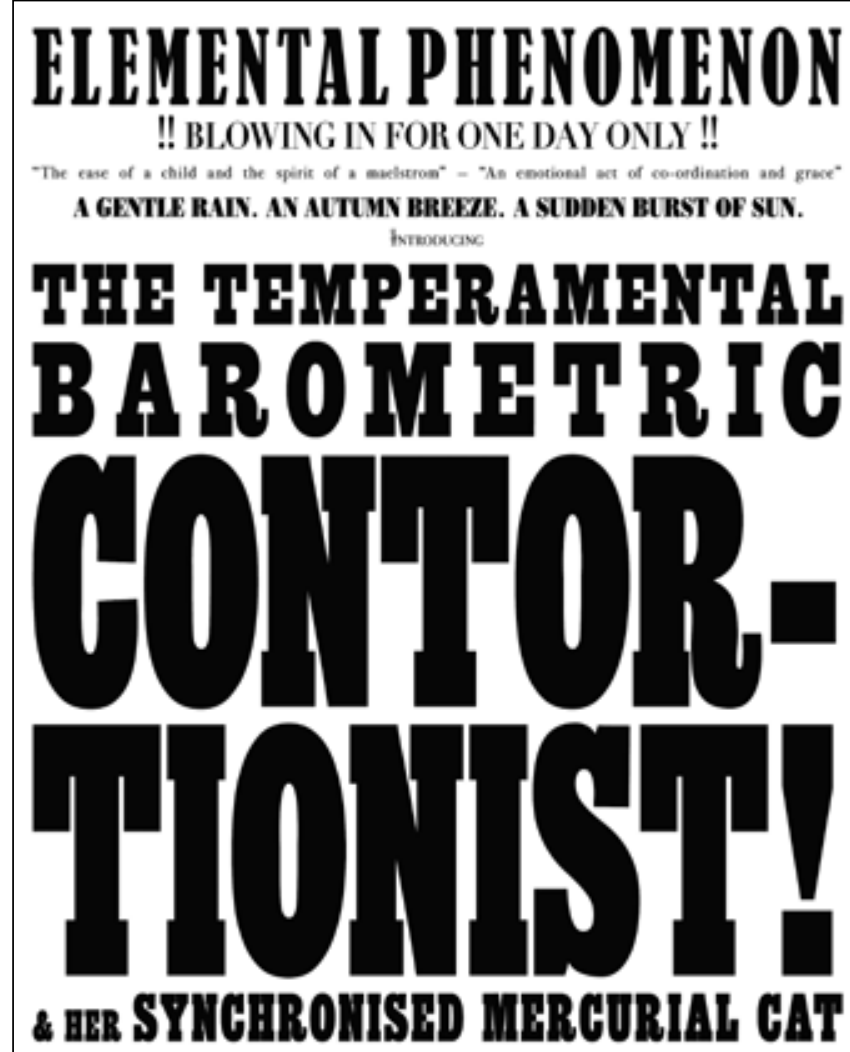

A changeable force commanding atmogpheric permutations of unthinkable influence as far as the eye can see. A PASSING CIII.L. A FLASII OF IIEAT. Experience subele shifts and dramatic modifications, Ups and Donens. Highs and Lons. Come prepared for the most cyclonic show of euremes ever imagined. THUNDER. L.IGHTNIG. SEISMIC TREMORS.

INEXHAUSTABL.E. INFINITELY VARIED. FEATS TOO NUMEROUSTO RFCOUNT.

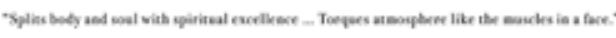

Figure 3. Janice Kerbel, Remarkable: Barometric Contortionist, 2007. Silkscreen on campaign poster paper, $165.5 \times 114.5 \mathrm{~cm}$ (Courtesy of greengrassi, London).

image of the words as a representation of the idea, but in the enhancement (or complication) of the reading/seeing process by the artist's typographical decisions. The resulting question is: How do these decisions position language as a contemporary critical medium?

Written language as the sole or dominant component within an art practice can be traced back to the late nineteenthcentury avant-garde. Art history tends to follow the trajectory from the figurative poetry of the French Symbolist Stephane Mallarmé at the turn of the last century to the word as material in Futurist poetry and the calligrammes of Guillaume Apollinaire, the word-image as an authority-challenging tool in the Dada and Surrealist movements, the appropriating advertising parlance of Pop, and finally, the word in Conceptual art, stripped down to the point that language itself became the artwork. Conceptual art is perhaps the most influential of these 


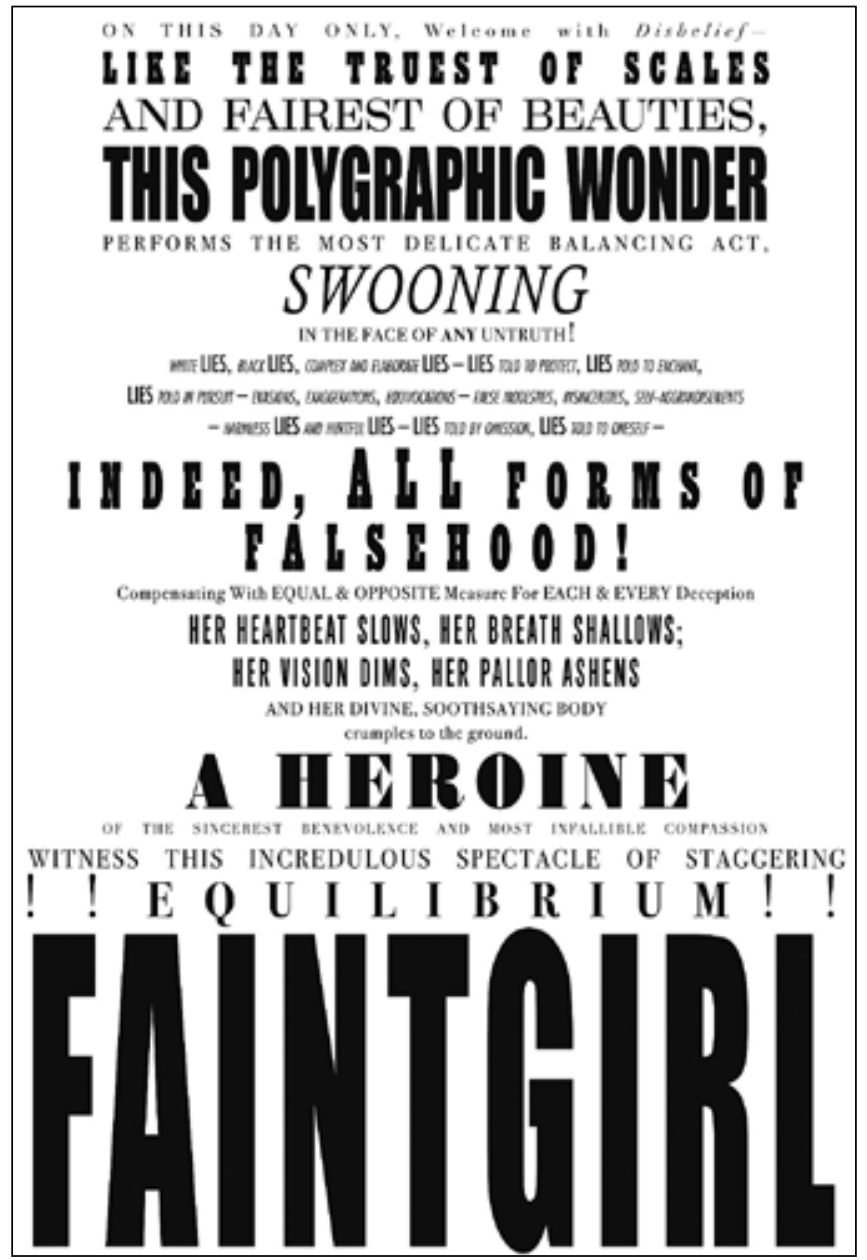

Figure 4. Janice Kerbel, Remarkable: Faintgirl, 2007. Silkscreen on campaign poster paper, $165.5 \times 114.5 \mathrm{~cm}$ (Courtesy of greengrassi, London).

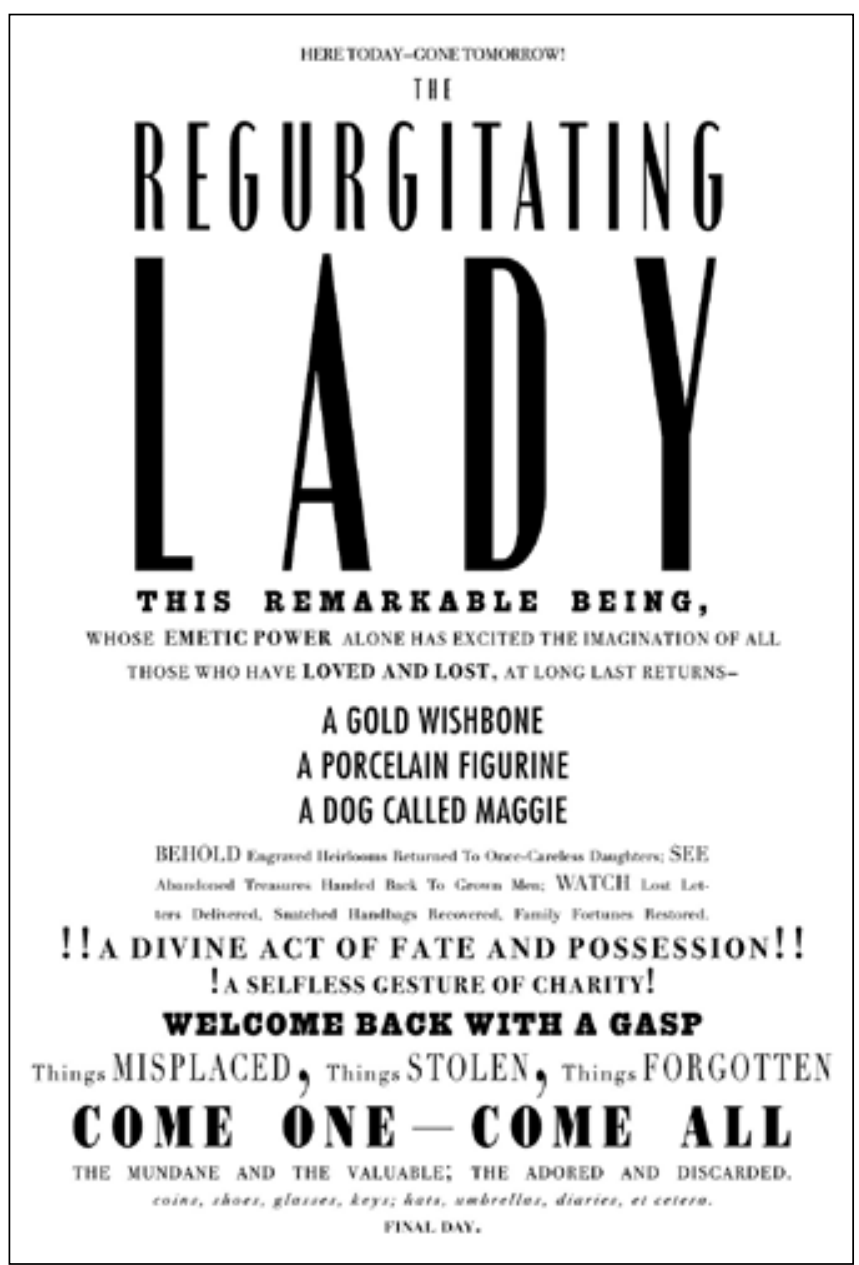

Figure 5. Janice Kerbel, Remarkable: Regurgitating Lady, 2007. Silkscreen on campaign poster paper, $165.5 \times 114.5 \mathrm{~cm}$ (Courtesy of greengrassi, London).

"poems [were] made not of ideas but of words," which were "transposed to take on new meanings." Such a concept necessitated "a structural design"6 that could be two-dimensional, in the form of a page, or three-dimensional, in the form of a sculptural cube; the particular form both guided readers and gave them agency. Broodthaers's work Un coup de dés reprises Mallarmés poem in book form, with black bars replacing the words. Broodthaers calls attention to Mallarmés discovery of the graphical and architectural potential of language as a subject and medium. ${ }^{7}$ However, since Broodthaers worked in poetry as well as the visual media of film and sculpture, his homage to Mallarmé is less surprising than that of Sol LeWitt. For LeWitt, what Mallarmé offered was a proposition for a new "rule-dominated anti-aesthetic system that generates its own style," according to Bernice Rose. ${ }^{8}$ Mallarmé carefully scripted rules for the reader who encounters a book presented as a cube. 


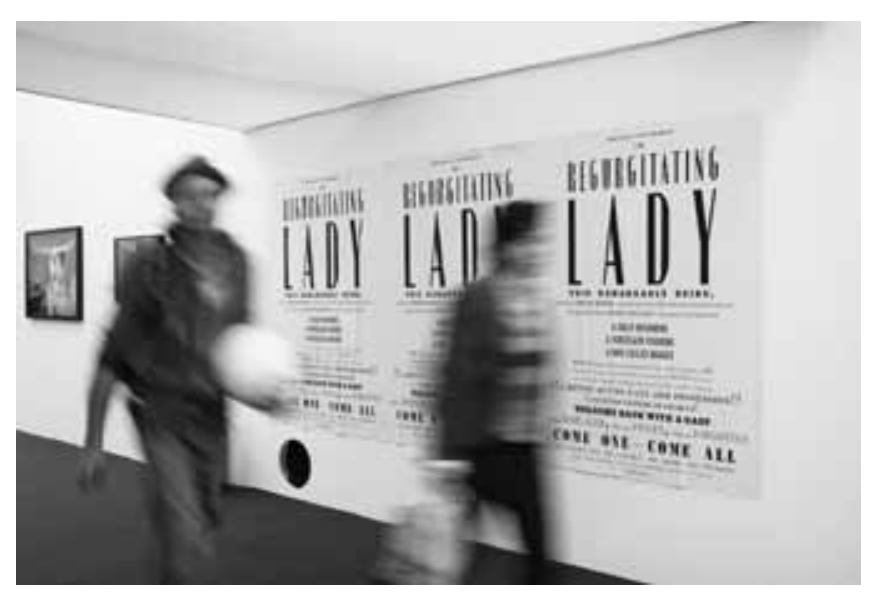

Figure 6. Janice Kerbel, Remarkable (installation), 2007, Frieze Art Fair, London (Photo: Polly Braden. Courtesy of greengrassi, London).

This was brought to LeWitt's attention by a 1964 article on Symbolism in a German music magazine. ${ }^{9}$ Rose argues that the article is perhaps one of LeWitt's most important sources, taking him toward the development of the artwork as a rule-dominated structure that then takes shape as a painting or sculpture by consequence of those rules. What then are the rules of perception that encourage the audience's agency when the model is not painting or sculpture but written language? Collectively, the twentieth-century avant-garde embraced and engaged written language as a tool and a medium, shaping an artistic culture within which the word is now firmly entrenched, but within Constructivism as well as Dada and Surrealism we can also see a paradox: the anti-aesthetic impetus of the turn to language yields a new style. We cannot escape the material. However, we can reconfigure and be critically aware of it.

Dadaists and Surrealists exploded language referents as a strategy to destabilize relationships of power and hierarchy within society, but the Conceptual art movement of the 1960s used language as a medium differently. ${ }^{10}$ Joseph Kosuth challenged our perception of the object in its representation in language, something seen by his distinguishing between the presentation of documentation of works and the works themselves. ${ }^{11}$ Kosuth did not want the two confused. This can be seen in the 1967 piece Titled (Art as Idea as Idea) [Universal], which he presented as a photostat, with the subtitle undermining any importance placed upon the material manifestation. Lawrence Weiner's work always allows for the possibility of its manifestation in endlessly adaptable representations not bound by a material specificity. His Declaration of Intent (1969) established the tenet within his practice of delegating the responsibility for each instantiation to the custodian of the work. Sol LeWitt juxtaposed words with drawings to create uncertainty as to which aesthetic action we should perform: looking or reading. In contrast, John Baldessari was very particular about the visual appearance of the text, hiring sign-painters to letter paintings in a script typical of commercial signage of the time. In Tips for Artists Who Want to Sell (1966-68) the block capitals are easily readable, but Baldessari creates hurdles (inconsistent hyphenation, orphans) for the reader, interjections into the typographic layout that call the reading process into question. Carl Andre's typewritten poems on paper can be associated with two movements: they were as much Conceptual propositions as they were visual works with the word as material, related to Concrete poetry. ${ }^{12}$ Within such divergent practices, it is impossible to generalize as to why the Conceptual artists who turned to language did so. But one can argue that language in the 1960s became a medium of choice for the various attributes it offered artists: accessibility and democratization (if you could read English, you could experience the artwork); portability (particularly in a newly globalized art world with artists participating regularly in international travel and exhibitions); affordability of material; and a material status that presented a brief conundrum - the art "object" as a new type of commodity. The attributes that made written language desirable also coincided with the emergence of the concept of the "dematerialization"13 of the art object, particularly in the writing of LeWitt and of critic Lucy R. Lippard, the two closely aligned and working out of New York in the late 1960s. There was an impossible contradiction within this notion, although Lippard did not refute it until 1978. The ways in which Conceptual artists were using written language, as well as other non-traditional media, had already demonstrated its falsity. 14

Within such a varied history, how are we retrospectively to define "Conceptual" to assess whether contemporary languagebased art indeed operates within the same framework? In a recent lecture, theorist Slavoj Zizek articulated the Hegelian concept of the idea as a notion or cause that always has within itself the potential for its own actualization. ${ }^{15}$ Bearing in mind that one of the early terms for Conceptual art was "Idea Art," what then is the role of language in actualizing the idea as it passes from artist to audience? The Greek root of "idea" is "to see"; so, how does reading the word enable us to see the artist's idea? Art historian Benjamin Buchloh argues that the question of "reading" or "seeing" text in Conceptual art was posed when artists presented a disorienting aesthetic proposition that left the audience with the tools to do either, but were forced by the work to choose a strategy. ${ }^{16}$ Buchloh also turns to LeWitt's Structures (1961-62) as an example of artwork that signals the integration of "language and visual sign in a structural model."17 Structures contains inscriptions that describe the support, the inscription itself, or an inversion of the two ("RED SQUARE," "WHITE LETTERS"), and Buchloh argues that the inscriptions "created 
a continuous conflict in the viewer/reader...not just over which of the two roles [reading and seeing] should be performed in relation to the painting" but also over "the reliability of the given information and the sequence of that information. Was the inscription to be given primacy over the visual qualities identified by the linguistic entity, or was the perceptual experience of the visual, formal, and chromatic element anterior to its mere denomination by language?" He goes on to argue that "the permutational character of the work suggested that the viewer/ reader systematically perform all the visual and textual options the painting's parameters allowed for," which "thereby suspend the reading of the painting between architectural structure and linguistic definition." 18 Buchloh's argument is particularly useful, not only as a revision of the understanding of written language in the act of seeing/reading in Conceptual art, but also as a model from which we can begin to question written language as a device in art today.

The relationship between visual and textual components of art continues to shift. Conceptual art largely adopted an anti-aesthetic, which can be seen in the collaborations initiated by the Lithography Workshop of the Nova Scotia College of Art and Design under Gerald Ferguson, with artists including Baldessari, LeWitt, and Dan Graham invited to the campus. ${ }^{19}$ Their lack of technical experience with lithographic printing yielded much reinvention of the medium. Ontario-based artist David Scott Armstrong, whose printmaking practice has addressed ideas of materiality and loss, observes, "Print is most commonly understood as a tool and a technology, with the intent and purpose of reproducing, storing, disseminating and communicating....It is to a large extent 'known' for being a kind of supporting player, a mechanical apparatus placed under in order to reproduce other words." 20 The same, I argue, could be said of typography-the tools and technique of designing, setting, and printing letterforms-in an art context. Armstrong argues that print's supporting role "produces a muteness that further underscores its present, yet hidden status. Unconsciously sensed, [but] broadly implicated." 21

The material manifestations that words take can serve to further a message via the visual codes of typography, but they can also problematize the reading process through disfluent ${ }^{22}$ typography or impact the message with unintended visual associations. Since the 1970s, there has been an increasing sophistication in the awareness among artists of the richness of typographical possibilities, in contrast to the somewhat ironic use of austere typography shared by much Conceptual art. Conceptual artists of the 1960s often chose production techniques for their pared-downness, but visual practice today, in the example of Janice Kerbel's work discussed here, elicits a productive exchange between concept (in this case a fantasy) and image.
Of the multiple movements of twentieth-century art in which the word was used by artists, only in the cases of Surrealism, Dada, and Constructivism has there been a great deal of attention to the typographical implications of the word on the work. I argue that contemporary language-based practice is more often heir to Conceptual art than to any other twentiethcentury movement involving text and word-image. However, the critical writing on "dematerialization" (despite Lippard's later pointing out its failings, and Buchloh's re-examination of historical Conceptual art) has resulted in contemporary discourse where the discussion of formal qualities of the medium of language is often perceived to be superfluous.

\section{More than Words}

But how is it that I do not speak that language of writing when I speak? I cannot write in the air with my voice. When I speak-no writing, only discourse.

Answer: the text needs the paper. It is in contact with the sheet of paper that sentences emerge.

Hélène Cixous 23

Janice Kerbel is an artist who writes. She has been based in London since completing her master's degree at Goldsmiths College in 1996, and prior to this she studied cultural anthropology at the University of British Columbia, perhaps fostering an early interest in research over studio practice. Having worked at an assortment of jobs, some in publishing, she was for a period a proofreader of crime fiction. Her practice is not exclusively text-based-she also makes sound pieces and installations. Among her varied projects are written plans, maps, scripts, and "situations." 24 Stemming from extensive research, her artwork explores seemingly unrelated subjects, from bank robberies to insomnia to the all-American game of baseball. Obsessive and meticulous, the work can be disorienting. The common thread among her projects is a highly researched, detail-oriented focus on the subjects that have taken hold of her imagination and have led her to create schematics in various media. Her 15 Lombard Street (2000) is an intensely detailed plan of a heist of a central London private investment bank. Nick Silver Can't Sleep (2006) is a radio play for insomniacs, and Home Fittings (2000-2004) is a series of architectural drawings indicating how to move through particular spaces without creating a sound or shadow. These and other recent works develop form for things that defy the visible. Given her meticulousness, it is ironic that she is working with language, something that is effable and uncontainable. 


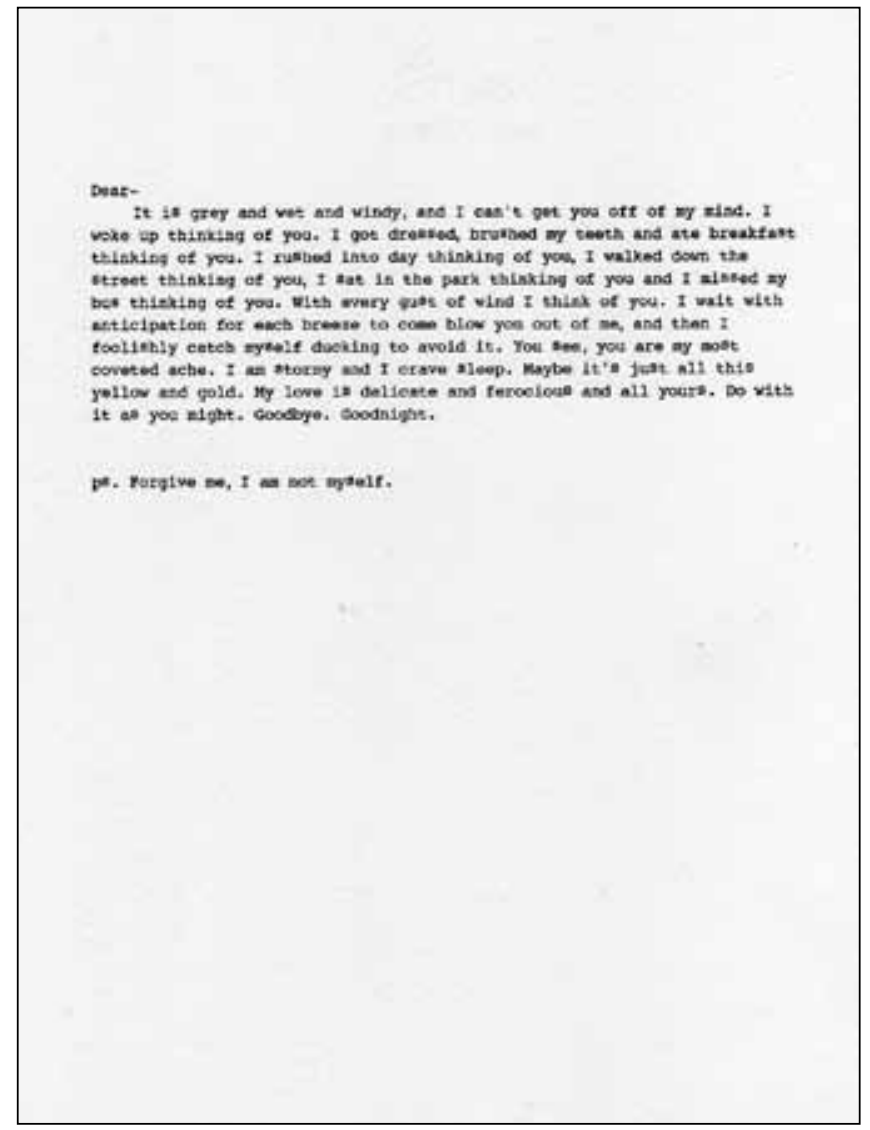

Figure 7. Janice Kerbel, Underwood (Fall), 2006. Digital inkjet print on paper, $29.7 \times 21 \mathrm{~cm}$ (Courtesy of greengrassi, London).

I first came across Kerbel's art when she read what was then a work in progress at an event organised by BookWorks, a publisher of artists' books. That work, Ballgame (Innings 1-3) (2009), has since been completed and shown at the London gallery greengrassi. A sound installation, Ballgame features a single speaker in an otherwise empty gallery space, broadcasting an announcer's voice reading a monologue script. ${ }^{25}$ (A script, of course, is writing meant to be heard not seen.) Initially, the recording seems to be a play-by-play of a typical baseball game, and in fact Kerbel's game is the most typical ballgame imaginable. She scoured baseball statistics to create an impossibly average game in terms of score, strikes, weather, players' names. The scripted game sits in the middle ground of statistical averages, yet the game will never happen. As in many of her works, the hook lies in the knowledge that it could happen. There is a potential there that Kerbel imagines and then harnesses, and in doing so, she creates a space in which language fills the air with waves, like the sound installations of Janet Cardiff, whose works treat voices and sounds as material to be sculpted.
Language is present in most of Kerbel's work. Underwood (2006-7) is a series of love letters to the seasons (not to another person). The title alludes to the work's mode of production: it consists of letters typed with a digital font based on a classic typewriter script (fig. 7). ${ }^{26}$ In Underwood Kerbel adjusts the script so that the letter " $\mathrm{s}$ " is aligned slightly higher than the main line of the text, suggesting a possible trace of the author, like that used by a police investigation to trace a ransom note. But this is a red herring, as it is a postscript digital font, and so untraceable to a single source. Making typographical interjections into the text, Kerbel calls our attention to the writer's hand-and to the machine mediating the process of creation from artist to text. Where Apollinaire used the typewriter as an integral component of the production and presentation of his calligrammes in a moment when it was closely associated with the written word, Kerbel pays homage to the Underwood brand in its virtual obsolescence. In his early development of language as a readymade, Duchamp also used the Underwood typewriter in several key works. In Fania (1916), Duchamp employed Underwood type to script a text that he made "gesturally crude" 27 by drawing over it with a linear profile of Carl Van Vetchen's wife (Fania), an exaggerated nose protruding from her face. In the same year, Duchamp presented the Underwood as a readymade in Traveller's Folding Item. Shown high on a stand, the cover draped over the heavy steel typewriter, it encourages the viewer to peer under the "skirt" to see what is hidden beneath. Duchamp solicits our voyeurism to see literally what is under the skirt: the typewriter, the hidden tool of production. "The onlookers are the ones that make the picture," as Duchamp remarks. ${ }^{28}$ The female figure in Fania is cloaked by words, the script typed over her face. To art historian David Joselit, the order reflected in the type in Fania is violently juxtaposed with the grotesque hand-drawn caricatural profile. For Kerbel, however, the typewriter and the type it produces are not something for masking, or being hidden, but tools that provide a tangible bridge between her imagined concept and our experience of it. This bridge is not always the shortest line between two points. Sometimes typography complicates it, disrupting the reading/ viewing process. In Underwood it is a trace of the author, but contains a red herring.

Where Underwood presents correlations to the Surrealist use of word-image, there is less correlation in Kerbel's work to Surrealist modes of production. In Remarkable the visual codes within the graphic mark of the letter allow Kerbel to reference her source and then point us somewhere else: to a fantasy, a fiction, or a near impossibility, which is a method traceable to Conceptual art. Liz Kotz, writing extensively on language art of the 1960s, comments on Robert Smithson's writings on language, "Although a word is defined by its contexts.... a word also constantly exceeds these contexts and goes elsewhere." 29 She 


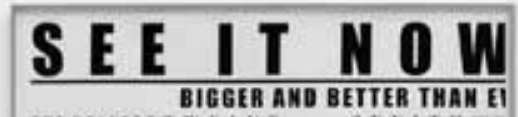

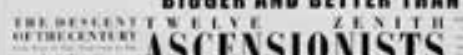
anowgruke ASCENSIO NISTS IACK, HAIREANG \& IRONJAW KNIFE

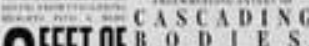
9.FET OF \& 60 D

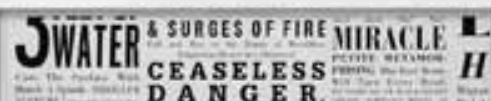

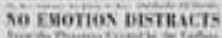
TURNIP RAPINI L I O N S DISCIPLINE. PANTHER The The Host Collosal Act of Skill and Darine the first

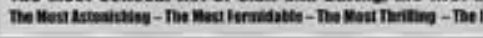

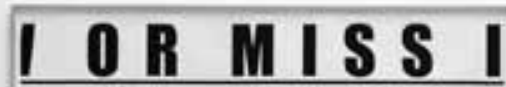
VER BEFORE - BAIN OR SHINE - A FOURT A URORA GRA C E SLENDER THREAD of SILVER Prieтвсivic NTen

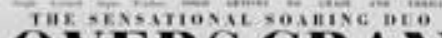
OVERG CRA N

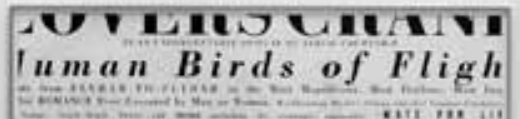
RISING OLT OF I SANDSTORM ARABIAB WIND FEATS OF MOVING SPIENDOUR lime ever in this country. The Mest antuan - Do west enet

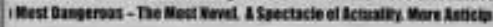
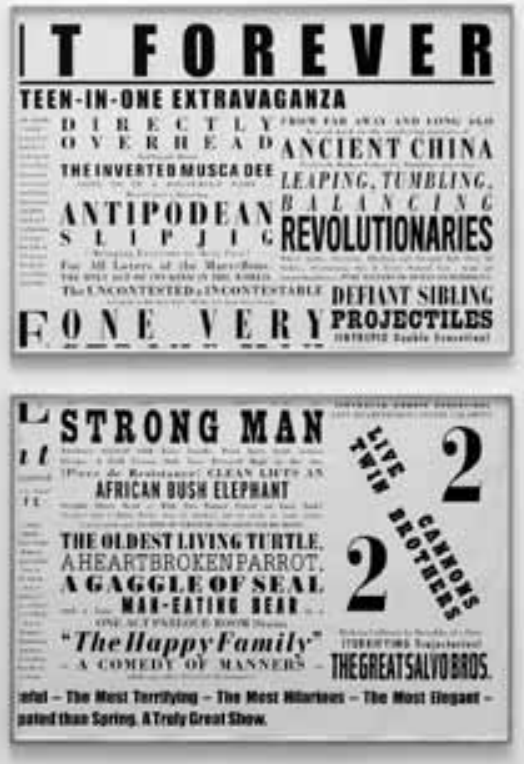

Figure 8. Janice Kerbel, Remarkable (installation), 20I0, Tate Britain, London (Photo: Polly Braden. Courtesy of greengrassi, London).

continues, "A term taken out of its normal context of use and resituated onto a blank page, for instance, or the wall of a gallery can do something else entirely." 30 One thing it can do is to become an image. Language in text-based art offers the potential to point us at an idea, and then move beyond that specificity to a potential defined by each reader. The visuality of the word enables this process. Smithson stated, "Look at any word long enough and you will see it open up into a series of faults, into a terrain of particles each containing its own void."31 To Smithson, words were physical matter, and spaces were physical gaps between them. The sculptural potential of Kerbel's work lies in these gaps. ${ }^{32}$

In the Remarkable series, the visual associations with Victorian popular culture resemble Kerbel's use of the Underwood font to pay homage to an outdated mode of communication. The type in Remarkable is an emphatically pre-modernist series of Egyptian or slab-serif fonts characterized by their blocky serifs. Such typography is antithetical to that used by Conceptual artists, who typically chose sans-serif typefaces lacking adorn- ment, such as Franklin Monotype Gothic (Lawrence Weiner) or Sabon (Joseph Kosuth). So, what is Kerbel's strategy? Despite being set digitally, both her typography and her layout emulate broadsides and speak to Victorian and pre-Victorian publishing and advertising more than they do to 1960 s Conceptual art. Broadsides were a form of street literature in which large sheets printed with woodcut on cheap paper were plastered onto walls. In use from the sixteenth century to the nineteenth century and losing importance only with the advent of mass-produced newspapers and cheap novels, they marked one of the first stages of the transition from the oral tradition of history and fiction to the written one. Kerbel's recalling of the broadside evokes an element of steampunk. 33 Though not actually printing broadside, ${ }^{34}$ Kerbel references the Victorian layout for such posters, running the text to the edge and using most of the available space to exploit the full width of the paper (fig. 3). Her posters also speak to the word in the context of Victorian advertising: technological developments in printing had led to increasing speed and decreasing cost as the nineteenth century ended, 
and this produced what Drucker calls a "visually cluttered environment" 35 of printed ephemera in which graphic design had to be executed with skill to grab readers' attention away from the competition.

In selecting to reference the broadside-an anachronistic method of distribution-in Remarkable, Kerbel creates an imagined, deceptive scene. Her non-narrative text tells us of characters and events in exaggerated detail, though we are never given a time or date with which to locate them. In other recent works, including Bank Job (1999), Kerbel has also created fantasy situations, with detail heightened to the point that the reader/viewer feels she could step into an imaginary world. The Bird Island Project (2000-2003) (www.bird-island.com) cleverly mimics the online marketing strategies of real estate time-shares sold "off-plan." While the design and layout pastiches the soft pastel hues, italicized fonts, and clunky web-page design of a real estate development, the language plays on the boredom that may lead someone to the site through a Google search for keywords like "paradise" or "tropical island." "You are on your way to becoming a partner in paradise," Kerbel writes. As with Remarkable, Kerbel invites us with her language and detail to share her vision for an imagined future in some far-flung place. The result is the often-dystopic realization that this future has already happened, or worse, never can. In Remarkable, the typography instigates this exchange, opening the reading up to Victorian notions of phantasmagoria and magic.

Given the context of the series in their first presentation at Frieze Art Fair, the lack of conventional information conjures up a commentary on the deception of the art world and the orchestration of events happening behind the green curtain. At Frieze, Kerbel's posters jostled for attention against the overabundance of artworks and frenzied collectors trying to do a deal. Her work clearly comments on the frenetic attitude of the art market at such events. The posters were fly posted on temporary surfaces so that each of them confronted the audience several times over, like an advertisement hung at intervals on hoardings, gaining visual impact from repetition. ${ }^{36}$ Ephemeral objects, broadsides, and playbills are generally destroyed when the next ones are put up. However, when moved to the Tate for Kerbel's solo exhibition and placed in frames, the works transcended their initial temporary status and the language bent to the new context (fig. 8). The critique reorients: it now comments on the institution and the mechanisation of art that it orders.

Scale is important here. Although there are abundant references to Victorian and prior methods of printing, it would have been impossible in earlier times to print the letters in Remarkable to such a height in metal type. Broadsides were meant to be read from a distance and so required large type, but twelve line pica was the largest feasible in metal type. Kerbel's typefaces can only exist in such size if they are digital (fig. 5). Also, when letters move apart from one another in the construction of a word, they instead become visual devices. It is her use of such devices to transform text into image, coupled with her focus on engaging the reader/viewer, that distinguishes Kerbel and other language-based contemporaries from their Conceptual predecessors. It is what makes Kerbel's work, I argue, uniquely contemporary: the artist manipulates language as a fiction with consideration to the material shape of words, not as a proposition or idea disembodied from the words that convey it to the audience. The fiction contained in Remarkable comments on the dystopic scene she renders and also on the false magic of the art world. Unlike Pop, Kerbel does not parody advertising parlance but instead manipulates the visual language of early graphic design within an art context, to produce a critique that works in various institutions. Her use of the visual and material quality of language as a medium makes this possible. She casts the writing not as writing but as art. The letterforms, and the gaps between them, give us something to hold on to, a material trace of the writerly experience of the work.

\section{Reading Blind: The Word in the Mind's Eye}

The work of art is a conductor from the artist's mind to the viewer's.

Sol LeWitt 37

The creative act is not performed by the artist alone; the spectator brings the work in contact with the external world by deciphering and interpreting its inner qualifications and thus adds his contribution to the creative act.

Marcel Duchamp 38

The text of a poster from Remarkable makes little sense if simply read from left to right. Instead, the experience of the work is seeing and visualizing the words and their referents, whether it be "the explosive beauty of the 'Human Firefly' Iggy Fantuse" or the "remarkable being of the regurgitating lady." 39 Are Kerbel's texts operating as signs? Art and design historian David Brett writes on the communicative intention of sign-making, arguing that the attention-getting gesture of the sign is not decoration (something he seeks to reaffirm as a critical discourse) but "graphicity." To Brett, graphicity is what occurs in the moment when "the denotative function of advertising...is clearly absorbed and almost lost" to the visual experience-when we no longer read signs but behold the spectacle. ${ }^{40}$ Graphicity is when words slip away and become purely visual. It is in this moment, something Smithson alludes to, that the real potential for the word to convey an idea is revealed. Brett uses the example of 
neon signs of characters in Asian cities at night. I argue that Kerbel's work could be seen to evoke a similar response in her audience in the space of the gallery.

In answering a question about Remarkable during a discussion I had with her, Kerbel read several lines of one of the posters aloud to herself: "Thunder. Lightning. Seismic tremors. Inexhaustible. Infinitely varied." 41 She commented that in the writing process, she knew how she arrived at a completed phrase, but that reading it left to right, top to bottom, made no sense to a viewer. 42 The viewer has to enter where he or she sees a gap and is drawn in, at the point that typographically grabs him or her. Kerbel's text is a process, a translation from thought to spoken to written, and once entered, the reader must continue the translation, from typographical mark to word to thought.

Kerbel wrote and set the text for Remarkable simultaneously: rather than writing the piece and then laying it out, adjusting fonts, sizes, and spacing, she developed the words and the way they look at the same time. Not only is this is unorthodox to both artists and to designers, but it is also in direct opposition to a significant shift in printing that occurred in the second half of the nineteenth century, the period to which Remarkable visually points. Drucker notes that in the Victorian period, "[f] or the first time, the tasks and responsibilities of visualizing a layout or sketching a composition were separated from those of printing," 43 a shift which marked the emergence of the graphic designer. Kerbel's approach implies that she pays equal consideration to how the text flows and to how the words look, how they relate to one another visually. In a contemporary context, the implication of digital publishing enables the discourse and the visuality to unfold at the same time.

In Double Attraction, Crystal and Blindspot, one poster from the Remarkable series (2007), the word "blindspot" sits seven lines up from the bottom of the page. It is in a much smaller point size than the rest of the text, and nearly hidden by the surrounding text. Written in uppercase sans serif, "blindspot" sits alone on a line, with words in larger typefaces above and below it, both typefaces with serifs. Is it a nudge for us to read between the lines? The word "blindspot" seems to remind us to look closely. Kerbel created a fantasy cast of sideshow performers for Remarkable, and Crystal and Blindspot are among them: Blindspot has only one eye and therefore limited peripheral vision and no capacity to judge distance. Hélène Cixous, in "Writing Blind," states that to write she must escape the day, which "prevents her from seeing." 44 Writing is a process which isolates her eyes and her mind. She states, "I cannot write without distracting my gaze from capturing. I write by distraction." 45 For Cixous, writing is seeing, and seeing only occurs in blindness, when the gaze diverts her from that at which she looks. The implication here: as an audience we receive the text in an indirect exchange. If the experience of reading/seeing is "writerly" in the Barthesian sense, then it is through distraction that the message emerges. Kerbel's typographical diversions in the reading process encourage us to engage with the text, through the gaps and distractions she provides. Cixous's essay "Writing Blind" and Kerbel's single, isolated word "blindspot" serve the same end, suggesting we read not to see the words but to look for the spaces between them, for the potential they hold in the creation of the message.

Kerbel's typography does not allow a smooth and efficient reading of the text, but rather provokes us to attempt to visualize her fantasy, to stumble over the words, and pausing as we do, to become trapped in the forms generated. Despite the visual quality of the word, we each see the fantasy differently. This is in contrast to LeWitt's work, which integrates language with its subsequent graphic manifestation. Lippard notes that LeWitt's The Location of Eight Points (1974) documents the increasingly complex instruction within it until reaching a point of "logical insanity," which she argues is a "prime example of the unique manner in which LeWitt has been able to use language as an integral part of his process, providing another, literal way of "reading the artist's mind." 46 The language of a text, title, or label may be deemed by the artist to be necessary as an intermediary between the idea/image and the audience, suggesting that language makes things more clear or exact when images are subjective. But language too is subjective, in part when it operates as descriptive text, and even more so when it operates as image, as in Kerbel's Remarkable.

\section{See it Now or Miss it Forever: The Word as Passage}

Typography is not always intended to be the most efficient way to communicate the message. At times, it places hurdles in the reading process, challenging the reader to question the information source and content in the process of perception. In postmodern graphic design of the 1980s, rules, grids, and lines were disregarded. Rick Poynor pinpoints the experimental typography at Cranbrook College of Art and Design, under the teaching of Katherine McCoy and her husband Michael, as a site for the emergence of a new discourse in graphic design, owing to the McCoys' teaching theory wherein a "visual transaction... parallels verbal communication....Students began to deconstruct the dynamics of visual language and understand it as a filter that inescapably manipulates the audience's response." 47 We experience passive confrontation with written language every day, particularly in an urban environment. Though this does not render the general population critical users of design, it does mean that the majority is savvy to the graphic devices with which we have become familiar. English artist Simon Patterson trades on this familiarity with The Great Bear (1992), which 
reworks the London Underground map. Poynor argues that artists like Patterson often make use of the recognizable visual codes of design, sometimes intentionally and sometimes clumsily or inadvertently. 48 Type operates differently in the contexts in which it appears: on a page, on a wall, in a gallery or outside of one. To discuss the typography in the work is to bring the interaction of the visual elements of the work into dialogue with the communication of the idea. Kerbel's work challenges the viewer to inhabit the text. Subjective experience is the component that only the audience can bring to the work, and it enables the work to be embodied, to have its concepts extracted and taken elsewhere.

Where much Conceptual art dealt with language as a proposition, Kerbel engages the word to convey a fiction. Within the fiction, words do not operate as narrative, but as image. We need a more refined vocabulary to discuss how contemporary text-based art communicates, critically integrating the visual quality of the word (its expression, mode of production, and distribution) with the text and its interpretation. In a digital age, it seems we are confounded by too much stuff, with verbal noise (both visual and oral) constantly streaming past us. When we can publish at the push of a button via Twitter, blogs, and live stream media, what does it mean to slow the process down, to labour over words, rendering them letter by letter? Despite the hyperbole in her non-narrative sequences, which are akin to tabloid headlines, and despite her typographic heightening of the melodrama of her text, Kerbel succeeds in slowing the process of reading. While we can see the words in Remarkable instantly, it takes time and effort to read them, and the path by which we read them is an individual one. Yet it is in their reading that their true potential unfolds.

The language-works to which I am drawn are ones that engage the viewer in the work through the process of reading in order to make a broader critique that challenges authority. That can be an authority of looking or of display-thus an institutional critique — or it can be one more aligned with identity politics. If artists are turning to language to explore its reflexive nature, what does written language and the materiality of the word offer uniquely to this project? Kerbel's text in Remarkable is a fiction in which the words operate as image. While her writing casts our interpretations of her words somewhere beyond the wall where they sit, her careful manipulation of the word as material gives us something to hold on to. In a digitized society, perhaps these material exchanges are more desirable than ever. Before these variables shift, the material word presents the opportunity to fix the circuit of artist, audience, and idea. It is a momentary exchange, as the title to the exhibition suggests. If we don't see it now, we will miss it forever.

\section{Acknowledgement}

I would like to thank the anonymous reader in the peer review process for very useful comments in editing this essay. Particularly I would like to acknowledge the excellent suggestion to use Benjamin Buchloh's article on reading/seeing in Conceptual art.

\section{Notes}

1 Roland Barthes proposes in $S / Z$ a distinction of "readerly" and "writerly" texts. In readerly texts, meaning is fixed and pre-determined so that the reader is a site merely to receive information. A writerly text, however, reveals elements that the readerly text attempts to conceal. The reader, now in a position of control, takes an active role in the construction of meaning. Reading becomes a self-conscious expression aware of the discrepancy between artifice and reality, destabilizing the reader's expectations. See Roland Barthes, S/Z, trans. Richard Miller (New York, 1974) 4-5.

2 Typography is, for the purpose of this essay, the visual and material quality of the letterform, the space around the words that compose the layout, the total visual experience of the artwork, and the modes of production and distribution by which the written words are rendered.

3 The terrain of the word-image as it emerged from Dada and Surrealism was comprehensively addressed by Judi Freeman in her touring exhibition and catalogue for the Los Angeles County $\mathrm{Mu}-$ seum in 1989. See Judi Freeman, The Dada and Surrealist Word Image (Cambridge and London, 1989). Artist-academic Johanna Drucker has written volumes on typography in early twentiethcentury avant-garde art, arguing for the fundamental materiality of the Dada, Futurist, and Cubist movements, in both visual and poetic media. Drucker contends that criticism had previously failed to appreciate the importance of materiality to these movements, and she turns her attention to typographic activity that furthered debates about the avant-garde. Drucker's more recent work has focused on digital aesthetics. See Johanna Drucker, The Visible Word: Experimental Typography and Modern Art 1909-1923 (Chicago, 1994).

4 Freeman, The Dada and Surrealist Word Image, preface.

5 Bernice Rose, "Sol LeWitt and Drawing," in Lucy Lippard, Bernice Rose, and Robert Rosenblum, Sol LeWitt, exh. cat., Museum of Modern Art, New York (New York, 1978), 34.

6 Rose, "Sol LeWitt and Drawing," 42.

7 Following the sudden death of Mallarmé in 1898, the work was not printed exactly to the author's specifications or to his marked corrections on the proofs. In 2004 French designer Michel Pierson et Ptyx printed ninety copies on vellum, based on the corrected proofs held in the Bibliothèque nationale de France.

8 Rose, "Sol LeWitt and Drawing," 34.

9 As cited in Rose, "Sol LeWitt and Drawing," 34. The original ar- 
ticle to which LeWitt refers is Hans Rudolf Zeller, "Mallarmé and Serialist Thought," trans. Margaret Shenfield, in die Reihe, no. 6 (Speech and Music) (Bryn Mawr, Pa., 1960).

10 Indeed as Rose proposes, Marcel Duchamp may be the first Conceptual artist for "his use of language images married to visual ones." Rose, "Sol LeWitt and Drawing," 34.

11 The summary of Conceptual approaches to language by artists Kosuth, Weiner, and LeWitt has been largely adopted and informed by the very helpful comments of the anonymous reader.

12 Concrete poetry is perhaps the most material manifestation of written language wherein the visual appearance of the words on the page reflects the content of the work.

13 Lippard writes on the "dematerialization of the art object" frequently through the 1970s and critiques her own earlier discourse in "The Structures, The Structures and the Wall Drawings, The Structures and the Wall Drawings and the Books," in Sol LeWitt, 27.

14 Lippard, "The Structures," 27.

15 Slavoj Zizek, "The Dialectics of the Present," Institute of Humanities Lecture, Birkbeck College, University of London, London, 23 March 2010.

16 Benjamin Buchloh, "Conceptual Art 1962-1969: From the Aesthetic of Administration to the Critique of Institution," October 55 (Winter 1990): 113.

17 Buchloh, “Conceptual Art 1962-1969," 113.

18 Buchloh, "Conceptual Art 1962-1969," 113.

19 Jayne Wark, "Conceptual Lithography at the Nova Scotia College of Art and Design," Journal of Canadian Art History / Annales d'histoire de l'art canadien 30 (Fall 2009): 60-88.

20 David Scott Armstrong, "Sfumato," After the Grave: Language and Materiality in Contemporary Art, Visible Language 42.1, Rhode Island School of Design (Providence, 2008), 19.

21 Armstrong, "Sfumato," 19.

22 Disfluency is a term used by neuroscientist Jonah Lehrer to describe fonts that slow the reading process through their low level of legibility, and that, somewhat surprisingly, have been shown to encourage the reader to retain more of the information contained within a message, perhaps due to the struggle the reader goes through to extract the message from the words. See C. DiemandYauman et al., "Fortune Favours the Bold (and the Italicized): Effects of Disfluency on Educational Outcomes," Cognition 118, 1 (January 2011): 111-15.

23 Hélène Cixous, "Writing blind: conversation with the donkey," Stigmata (London, 1998), 149.

24 Jennifer Higgie, "Get it While You Can," Frieze 77 (September 2003): http:/www.frieze.com/issue/article/get_it_while_you_can/

25 Kerbel has stated in Frieze ("Ideal Syllabus," Frieze 118 [October 2008]) that the prologue of Don DeLillo's Underworld is one of the texts that has influenced her most, calling it a "long, single, magnificent breath chasing the journey of a baseball." DeLillo stated that he spent much of his childhood, in the Bronx, New
York, wandering the streets pretending to be a baseball announcer. Kerbel also cites Emily Dickinson's poems as an influence for their "typographic eccentricities." The poet is known for her extensive use of dashes and capitalization.

26 Underwood was the first widely available and mass-produced heavy steel typewriter, most popular in the interwar period.

27 David Joselit, "Between Reification and Regression: Readymades and Words," in Infinite Regress: Marcel Duchamp 1910-1941 (Cambridge, Mass., 2001), 89.

28 Marcel Duchamp, quoted in Jean Schuster, "Marcel Duchamp, vite," le surrealism, meme 2 (Spring 1957): 143.

29 Liz Kotz, Words to be Looked At: Language in 1960s Art (Cambridge, Mass., 2007), 4.

30 Kotz, Words to be Looked At, 4.

31 Robert Smithson, "A Sedimentation of the Mind: Earth Projects (1968)," reprinted in Robert Smithson: The Collected Writings, ed. Jack Flam (Los Angeles, 1996), 107.

32 Using InDesign, Kerbel sets the type digitally, albeit in a slightly "analogue" way: she drops each letter in individually as an outline. This makes the kerning less measured than if she were using the software in a standard way. However, the gaps lack the material trace they would possess if set manually in letterpress with picas demarking the space.

33 Steampunk is a sub-genre of science fiction in which alternate histories are set in the nineteenth century, in an era when industry was powered by steam. Works of steampunk often present an anachronistic relationship to invention or technology, reimagining art, culture, architecture, and technology as Victorians may have envisaged them.

34 Also known as broadsheet, this is a method of printing a large sheet of paper on one side only. Traditionally used for posters and proclamations, the technique and term also applies to newspapers that were historically printed in the same mode.

35 Johanna Drucker, Graphic Design (Upper Saddle River, N.J., 2009), 141.

36 Frieze has commissioned artists since its inception in 2003. Frieze Art Fair is co-directed by Matthew Slotover and Amanda Sharp and was founded in 2003 by the two, who are also co-publishers of Frieze magazine. The organization also includes the Frieze Foundation, the non-profit component responsible for "the curated programme at Frieze Art Fair, comprising artist commissions, talks, films, music and education. Frieze Foundation is funded by the European Commission's Culture 2007 programme and Arts Council England" (Frieze.com). In 2004, the sales at the weekend fair totaled $£ 26$ million. After 2005 , figures were no longer released, as they were felt to be misleading due to the sales completed outside of the gallery and the curatorial program. Frieze also has a direct relationship with the Tate, through the acquisitions fund Outset, which is the first acquisition fund connected to an art fair. Other significant art fairs much longer established have recently 
begun commissions strands, most notably the Armory Show in New York in 2002.

37 Sol LeWitt, unpublished interview with Lucy R. Lippard, Archives of American Art, early 1970s, 1. (As cited in Anna Lovatt, "On Drawing: Ideas in Transmission: LeWitt's Wall Drawings and the Question of Medium,” Tate Papers 14, 2010: 1-14.)

38 Marcel Duchamp, Session on the Creative Act, Convention of the American Federation of Arts, Houston, Texas, April 1957. Published in Robert Lebel, Marcel Duchamp (London, 1967), 77-78.

39 Janice Kerbel, Remarkable, 2007-10.

40 See David Brett, Rethinking Decoration: Pleasure and Ideology in the Visual Arts (New York, 2005), 252.

41 Janice Kerbel, Remarkable: Barometric Contortionist, 2007.

42 Janice Kerbel, interview with the author, London, 8 September 2010.

43 Drucker, Graphic Design, 141.

44 Cixous, "Writing blind," 139.

45 Cixous, "Writing blind," 139.

46 Lippard, "The Structures," 28.

47 Katherine McCoy and Michael McCoy, "The New Discourse," in Hugh Aldersey-Williams et al., Cranbrook Design: The New Discourse (New York, 1990), 16. Quoted in Rick Poynor, No More Rules: Graphic Design and Postmodernism (London, 2003), 51.

48 Rick Poynor, "Syncretisms and Convergences," keynote address, $A C \mid D C$ Contemporary Art Contemporary Design, Geneva University of Art and Design (Geneva, 2009), 38. 